\title{
環椎外側塊スクリューと軸椎椎弓根/椎弓スクリューを用いた 後方固定術の経験
}

\author{
石 原 俊 信* 宮 崎 正 志* 吉 岩 豊 三* 津 村 弘*
}

環軸関節不安定症に対して環椎外側塊スクリューと軸椎椎弓根/椎弓スクリューを用いた後方固定術を 施行した症例ついて，解剖学的および臨床的に検討した。【対象】 2008 年から 2013 年にかけて C 1-C 2 後方固定術を行った 7 例で，平均年齢は 68 歳，術後平均経過観察期間 28 ヶ月であった.【方法】検討項 目として，後弓最狭部径，椎骨脳底動脈の走行と形態，C $1 / \mathrm{C} 2$ 刺入法，手術時間，出血量，神経血管合 併症，骨癒合率，C 1-C 2 angle，Ranawat の疼痛評価・神経機能評価を用いた。【結果】後弓最狭部径は 平均 $3.45 \mathrm{~mm}$ で，径 $4 \mathrm{~mm}$ 未満は $9 / 14$ で $64 \%$ であり，C 1 刺入法は Tan 法 3 例， notch 法 4 例であっ た。いずれの症例においても術中・術後神経血管合併症はなく，1例で骨癒合が得られず為関節となった 症例があったが，その他 6 例は骨癒合が得られインプラントの緩みや矯正損失は無かった.

Key words : C 1 lateral mass (環椎外側塊), C 1 lateral mass screw (環椎外側塊スクリュー), posterior arch (後弓), atlantoaxial fixation（環軸椎固定術）

\section{背景および目的}

環椎外側塊スクリュー（以下 C 1-LMS）と軸椎椎 弓根/椎弓スクリュー（以下 C 2-PS/LS）による環軸 椎固定術は，環軸関節不安定症に対して近年普及しつ つある。現在，当科においてもC 1-LMS と C 2-PS/ LS 法を用いた固定術を行っており，その成績および スクリュー刺入法による違いを，解剖学的および臨床 的に検討し，若干の文献的考察を加え報告する．

\section{対象}

対象は 2008 年 8 月から 2013 年 3 月に当科で，C 1LMS と C 2-PS/LSを用いた後方固定術を施行した 7 症例で，男性 4 例，女性 3 例，平均年齢は 68 歳，術 後平均経過観察期間 28 ケ月であった. 疾患内訳は RA に伴う環軸椎亜脱臼 3 例, 非 RA 性の環軸椎亜脱臼 2 例，外傷性環椎脱臼 1 例，歯突起骨折後偽関節 1 例で あった。

\section{方法}

検討項目として，後弓最狭部径，椎骨脳底動脈の走 行と形態，C $1 / \mathrm{C} 2$ 刺入法，手術時間，出血量，神経 血管合併症，骨癒合率，C 1-C 2 angle，Ranawatの 疼痛評価・神経機能評価を用いた。後弓最狭部径は, 術前 CT sagittal 像にて刺入部における最狭部上下幅

を計測した（図 1).

結

後弓最狭部径は平均 $3.45 \mathrm{~mm}$ で，径 $4 \mathrm{~mm}$ 未満は 9/14 で 64\% であった（表 1)，椎骨脳底動脈について は high ridingVA 3 例, VA 径の左右差が 2 対 1 以上 が 3 例, ponticulus posticus が 2 例，後交通動脈の欠 損もしくは低形成が 4 例であった。C 1 刺入法は Tan 法 3 例, notch 法 4 例, C 2 刺入法は両側 PS が 2 例, 片側 PS ・対側 LS が 5 例であった。2 例は中下位頝椎 の椎弓形成術も併用した。平均手術時間は 212 分，平 均出血量は $186 \mathrm{~g}$ （椎弓形成術を併用した 2 例は除 く)，神経血管合併症はいずれの症例においても認め

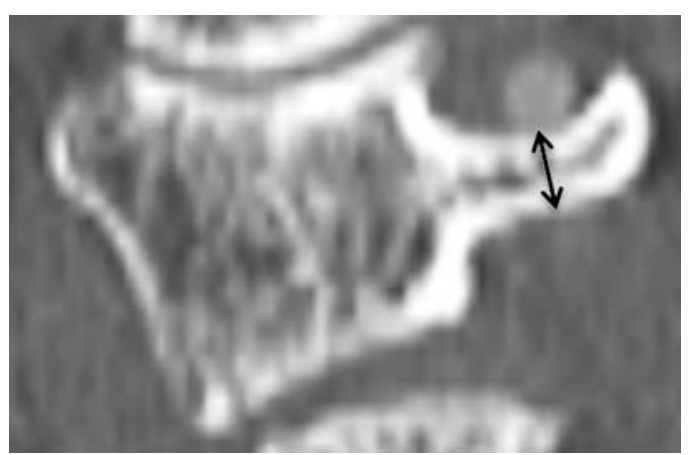

図 1 後弓最狭部径は CT sagittal 像で計測.

* 大分大学整形外科 
なかった，C1刺入法別では，notch 法に比し，Tan 法において出血量が $90 \mathrm{~g}$ と少ない傾向にあった (表 2)，骨癒合率は $85.7 \%(6 / 7$ 例）で，1例で偽関 節となり追加で後頭頝椎固定術を施行した。平均 C 1 C 2 angle は $20^{\circ}$ 目標とし，23.4であった。 Ranawat の神経機能評価では外傷性環椎脱臼と, 偽 関節となったClass III B の 2 例で不変であったが，そ の他，いずれの症例においても改善を認めた（図 2).

\section{症例}

症例 $1: 71$ 歳男性

交通外傷による，Anderson III 型の歯突起骨折に対 して, halo vest装着による保存療法を行ったが，偽 関節となったため C 1-C 2 後方固定術の方針とした (図 3). C 1 は後弓最狭部径が右 $2.83 \mathrm{~mm}$, 左 3.47

表 1 後弓最狭部径

\begin{tabular}{c|c|c}
\hline \hline case & 右 $(\mathrm{mm})$ & 左 $(\mathrm{mm})$ \\
\hline 1 & 3.82 & 3.92 \\
\hline 2 & 3.38 & 2.03 \\
\hline 3 & 3.13 & 4.13 \\
\hline 4 & 4.25 & 4.03 \\
\hline 5 & 4.01 & 4.00 \\
\hline 6 & 2.59 & 2.72 \\
\hline 7 & 2.83 & 3.47 \\
\hline \multirow{2}{*}{ 平均 $\pm \mathrm{SD}$} & $3.43 \pm 0.58$ & $3.47 \pm 0.74$ \\
\cline { 2 - 3 } & \multicolumn{2}{|c}{$3.45 \pm 0.67$} \\
\hline
\end{tabular}

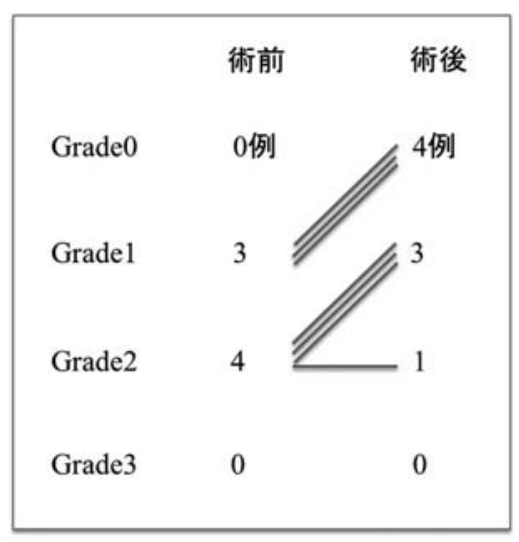

疼痛 $\mathrm{mm}$ と狭かったため，Tan 法での刺入は困難と考え notch 法での刺入を行い, C 2 は high ridingVA なと なく，椎弓根径が保たれていたので，両側とも PSで の刺入を行った。神経血管合併症なく術後 8 ケ月で骨 癒合が得られた（図 4).

\section{考察}

環椎外側塊スクリューの刺入法として，後弓に直接 刺入する Tan 法 $^{10)}$ ，後弓下縁をドーム状に削る notch 法 $^{5)}$, 外側塊に直接刺入する Goel 法 ${ }^{2)}$ の 3 通りが知ら れている (図 5)。Tan 法は解剖学的に外側塊周囲静 脈叢からの出血と C 2 神経根障害のリスクを低減でき る利点を有しており，水谷らはGoel 法に比べ，出血 量, 神経根障害, 引き抜き強度の点でTan 法が優れ ていることを報告している ${ }^{8)}$ ここれらの，C 2 神経根 · 静脈叢の処置と固定性の観点から，当科では Tan 法 での刺入を第 1 選択としており，今回の症例において も，Tan 法では C 2 神経根障害を認めず，出血量は $90 \mathrm{~g}$ と少ない傾向にあった。

ただし，一般的に $3.5 \mathrm{~mm}$ 径以上のスクリューを刺

表 2 C 1 刺入法別の成績

\begin{tabular}{cccc}
\hline \hline & Tan 法 & notch 法 & 全体 \\
\hline 平均手術時間 & 203 分 & 227 分 & 212 分 $(178-244)$ \\
平均出血量 & $90 \mathrm{~g}$ & $330 \mathrm{~g}$ & $186 \mathrm{~g}(80-330)$ \\
神経血管合併症 & $0 / 3$ 例 & $0 / 4$ 例 & $0 / 7$ 例 \\
\hline ※手術時間, 出血量は椎弓形成術を併用した2 例を除く
\end{tabular}

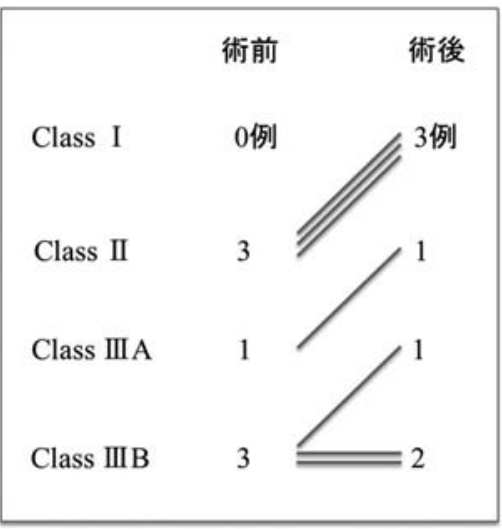

神経機能

図 2 Ranawat の評価基準 


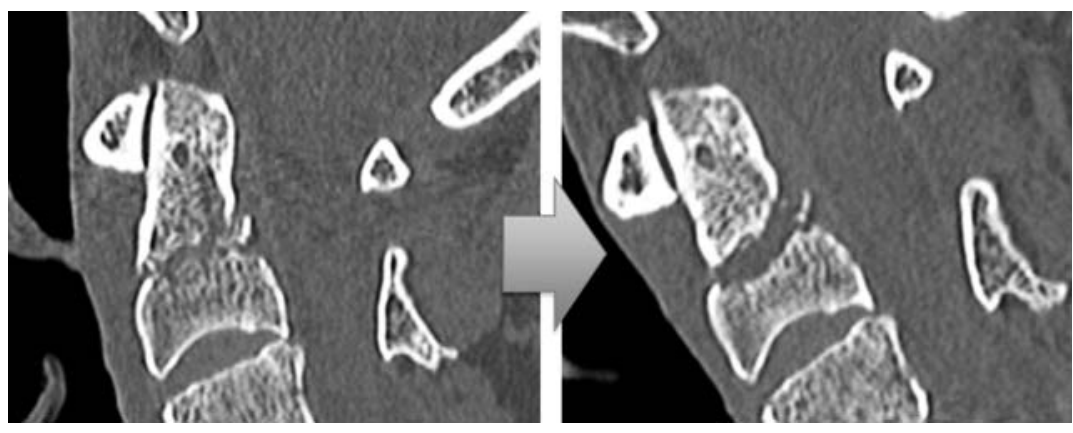

図 3 受傷直後と halo vest 装着 2 ケ月後の CT 像

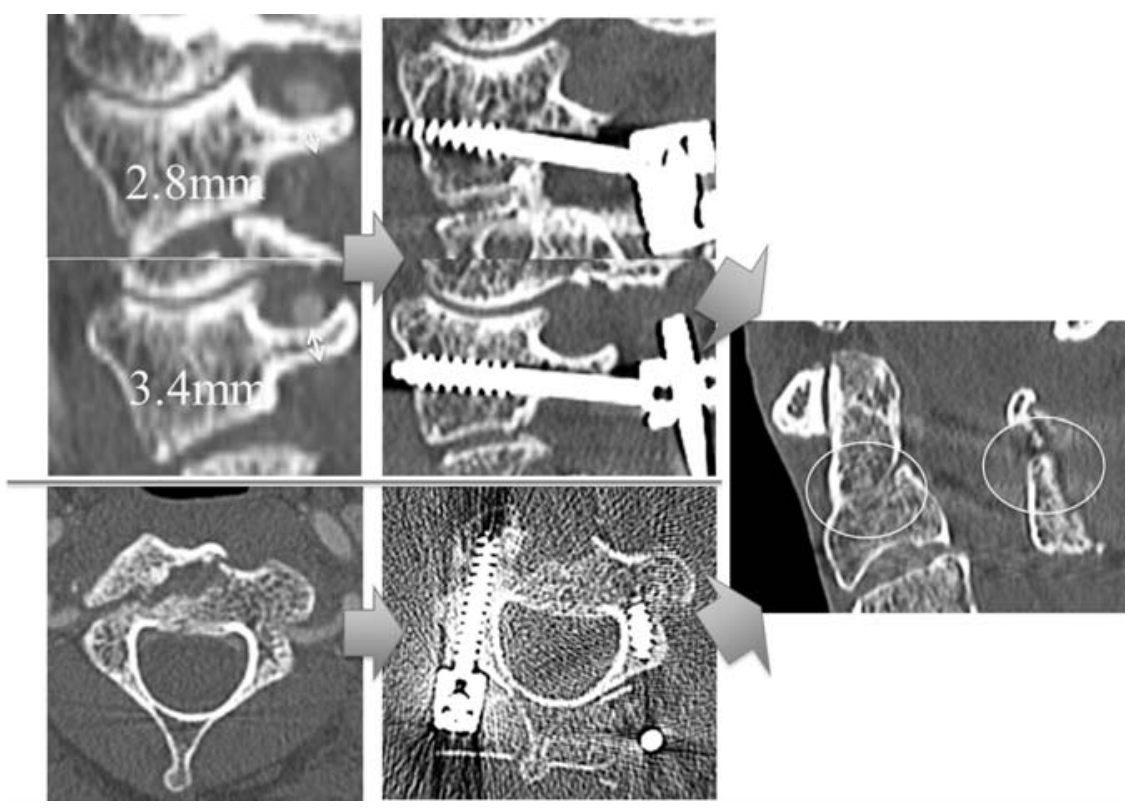

図 4 術前後 $\mathrm{CT}$ 像と術後 8 ケ月時 $\mathrm{CT}$ 像
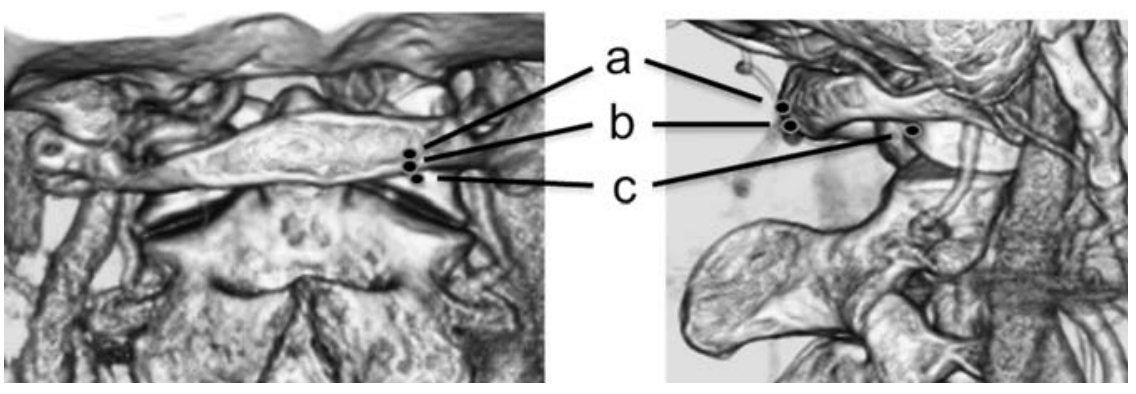

図 5 環椎外側塊スクリューの刺入点 $a$ ：Tan 法 b：notch 法 $c$ ：Goel 法 
表 3 後弓径と $4 \mathrm{~mm}$ 未満の割合における人種間の比較

\begin{tabular}{|c|c|c|c|c|}
\hline \multicolumn{2}{|c|}{ subject } & \multirow{2}{*}{$\begin{array}{c}\begin{array}{c}\text { 平均後弓径 } \\
(\mathrm{mm})\end{array} \\
4.58\end{array}$} & \multirow{2}{*}{$\begin{array}{c}4 \mathrm{~mm} \text { 未満 } \\
(\%)\end{array}$} & \multirow{2}{*}{$\begin{array}{c}\text { reference } \\
\text { Tan et al. } 2003^{10)}\end{array}$} \\
\hline Chinese & Dried human & & & \\
\hline Chinese & Dried human & 4.25 & 12 & Ma et al. $2005^{7)}$ \\
\hline Chinese & Patiens & 4.43 & 23.3 & Qian et al. 2013 ${ }^{9\rangle}$ \\
\hline Americans & Dried human & 3.95 & 53.8 & Lee et al. $2006^{5)}$ \\
\hline Americans & Dried human & 4.80 & 19.2 & Christensen,et al. $2007^{1)}$ \\
\hline Americans & Patients & 4.90 & 不明 & James et al. 2013 ${ }^{6)}$ \\
\hline Japanese & Dried human & 4.25 & 39 & Kobayashi,et al. 2008 \\
\hline Japanese & Patients & 4.10 & 44 & 久保ら 2010 \\
\hline Japanese & Patients & 3.45 & 64 & 当科症例 \\
\hline
\end{tabular}

入するため, Tan 法では後弓径 $4 \mathrm{~mm}$ 末満の症例で は，椎骨動脈溝への穿破のリスクが高くなり，刺入に 適さないとされている. Tan ら ${ }^{10)}$ は 50 例の Chinese の屍体のデータとして, 平均後弓径は $4.58 \mathrm{~mm}$, 後 弓径 $4 \mathrm{~mm}$ 未満は $8 \%$ と報告しているが，今回の当科 の症例に打いては平均後弓径は $3.45 \mathrm{~mm}$, 後弓径 4 $\mathrm{mm}$ 未満は $64 \%$ であり Tan 法での刺入困難例が多 かった．諸家の報告を並べたものを表 3 に示すが，日 本人を対象にした報告では，海外の報告に比べ平均後 弓径が小さく, 径 $4 \mathrm{~mm}$ 未満の割合が多い傾向にあり, 本邦ではTan 法でのスクリュー刺入困難例が多い可 能性がある。その際は notch 法, Goel 法で刺入する こととなるため, 外側塊周囲静脈叢からの厄介な出血 を最小限にとどめる目的で，コットンなどで静脈叢を 圧迫しつつ，なるべく外側塊の頭側から刺入するなど の工夫が必要となる。

安全に環椎外側塊スクリューと軸椎椎弓根/椎弓ス クリューを刺入するためには, 術前 CTで後弓径や VA の走行などを詳細に検討し, 刺入法を決定するこ とが重要であると考えられる.

\section{結語}

(1) C 1-LMS と C 2-PS/LS を用いた後方固定術の 7 症 例を経験した。

(2)本邦では海外に比べ Tan 法でのスクリュー刺入困 難例が多い可能性があるが，今後も症例を積み重ね ていく必要がある。

\section{参 考 文 献}

1) Christensen, D. M., et al. : C 1 anatomy and dimensions relative to lateral mass screw placement. Spine, $32: 844-848,2007$.

2) Goel, A., Laheri, V.: Plate and screw fixation for atlantoaxial subluxation. Acta Neurochir. (Wien), 129:47-53, 1994.

3) Kobayashi, Y., et al.: Insertion of lateral mass screw of the atlas via the posterior arch: anatomical study of screw insertion using dry bone samples of the atlas from Japanese cadavers. J. Orthop. Sci., 13:452-455, 2008.

4）久保紳一郎ほか：環椎外側塊スクリュー法の安全性評 価. 整外と災外，59：14-17, 2010.

5) Lee, M. J., Cassinelli, E., Riew, K. D.: The feasibility of inserting atlas lateral mass screws via the posterior arch. Spine, $31: 2798-2801,2006$.

6) Lin, J. M., et al. : C 1 lateral mass screw placement via the posteror arch: a technique comparison and anatomic analysis. Spine, 38 : 1549-1555, 2013.

7) $\mathrm{Ma}, \mathrm{X}$. Y., et al. : Anatomic considerations for the pedicle screw placement in the first cervical vertebra. Spine, $30:$ 1519-1523, 2005.

8）水谷 潤 : 環椎外側塊スクリュー固定一Goel 法. 脊椎 脊䯣, $26: 973-980,2013$.

9) Qian, L. X., et al. : Morphology of the atlas pedicle revisited : a morphometric CT-based study on 120 patients. Eur. Spine J., 22 : 1142-1146, 2013.

10) Tan, M., et al. : Morphometric evaluation of screw fixation in atlas via posterior arch and lateral mass. Spine, $28: 888-895,2003$ 